\title{
Correction to: Rapid Cycle Implementation and Retrospective Evaluation of a SARS- CoV-2 Checklist in Labor and Delivery
}

\author{
Liana Zucco ${ }^{1}$, Nadav Levy ${ }^{1}$, Yunping Li ${ }^{1}$, Toni Golen², Scott A. Shainker², Philip E. Hess ${ }^{1}$ and \\ Satya Krishna Ramachandran ${ }^{1 *}$
}

\section{Correction to: BMC Health Serv Res 21, 775 (2021) https://doi.org/10.1186/s12913-021-06787-5}

Following publication of the original article [1], the caption to Fig. 1 was inadvertently truncated. The correct caption should be:

Rapid cycles of change. Schematic representation of rapid-cycle implementation, demonstrating how the individual processes of inter-professional input, testing in real-time, focused debriefing, on-site walkthroughs and iterative re-design contributed to our final refined product. CFIR: Consolidated framework for implementation research, L\&D: labor and delivery.

The original article [1] has been updated.

\section{Author details}

'Department of Anesthesia, Critical Care and Pain Medicine, Beth Israel Deaconess Medical Center, 330 Brookline Avenue, Boston, MA 02215, USA. 2Department of Obstetrics, Gynecology and Reproductive Medicine, Beth Israel Deaconess Medical Center, Boston, MA, USA.

Published online: 18 August 2021

\section{Reference}

1. Zucco, et al. Rapid Cycle Implementation and Retrospective Evaluation of a SARS-CoV-2 Checklist in Labor and Delivery. BMC Health Serv Res. 2021;21: 775. https://doi.org/10.1186/s12913-021-06787-5.

The original article can be found online at https://doi.org/10.1186/s12913021-06787-5.

* Correspondence: skrama@bidmc.harvard.edu

${ }^{1}$ Department of Anesthesia, Critical Care and Pain Medicine, Beth Israel Deaconess Medical Center, 330 Brookline Avenue, Boston, MA 02215, USA

Full list of author information is available at the end of the article

(c) The Author(s). 2021 Open Access This article is licensed under a Creative Commons Attribution 4.0 International License, which permits use, sharing, adaptation, distribution and reproduction in any medium or format, as long as you give appropriate credit to the original author(s) and the source, provide a link to the Creative Commons licence, and indicate if changes were made. The images or other third party material in this article are included in the article's Creative Commons licence, unless indicated otherwise in a credit line to the material. If material is not included in the article's Creative Commons licence and your intended use is not permitted by statutory regulation or exceeds the permitted use, you will need to obtain permission directly from the copyright holder. To view a copy of this licence, visit http://creativecommons.org/licenses/by/4.0/. The Creative Commons Public Domain Dedication waiver (http://creativecommons.org/publicdomain/zero/1.0/) applies to the data made available in this article, unless otherwise stated in a credit line to the data. 